\title{
Upaya Guru Pendidikan Agama Islam dalam Menanamkan Nilai Karakter Religius
}

\author{
Intan Mayang Sahni Badry', Rini Rahman² \\ imsbadry@gmail.com ${ }^{1}$,rinirahman@fis.unp.ac.id ${ }^{2}$ \\ Universitas Negeri Padang ${ }^{1,2}$
}

\begin{tabular}{l}
\hline ARTICLE INFO \\
\hline Article history: \\
Received, 21 October 2021 \\
Revised, 09 November \\
2021 \\
Accepted, 30 November \\
2021 \\
\hline
\end{tabular}

\section{Keywords:}

Guru, Pendidikan Agama

Islam, Nilai Karakter,

Religius

\section{Clonflict of Interest:}

None

\section{Funding:}

None

\begin{abstract}
Penelitian ini bertujuan untuk mengungkapkan informasi dan membahas tentang upaya guru pendidikan agama Islam dalam menanamkan nilai karakter religius di kelas IX SMP Negeri 40 Padang. Jenis penelitian ini adalah penelitian lapangan (field research) dengan metode penelitian kualitatif. Sumber data utama penelitian ini adalah guru pendidikan agama Islam kelas IX, sedangkan sumber data pendukung yaitu wakil kesiswaan SMP Negeri 40 Padang, wakil kurikulum SMP Negeri 40 Padang, guru pendidikan agama Islam kelas VII dan VIII serta peserta didik kelas IX. Data diperoleh melalui observasi, wawancara, dan dokumentasi. Berdasarkan hasil penelitian, upaya yang dilakukan guru pendidikan agama Islam dalam penanaman nilai karakter religius dapat dikategorikan menjadi upaya di dalam pembelajaran dan di luar pembelajaran. Upaya di dalam pembelajaran dengan salam dan berdo'a, mengecek shalat siswa melalui absensi, literasi Alquran, pembiasaan shalat dhuha, dan infaq. Sedangkan penanaman karakter religius di luar pembelajaran melalui program tahfizh, wirid pagi Jum'at, nasehat, shalat berjamaah komunikasi dengan orangtua, serta kerjasama dengan masjid.
\end{abstract}

Corresponding Author: Intan Mayang Sahni Badry, Department Islamic Education, Faculty of Social Science Universitas Negeri Padang, Indonesia, Email: imsbadry@gmail.com Phone: $+62831-7896-4715$

\section{Pendahuluan}

Penanaman dan penguatan nilai-nilai karakter dalam masa sekarang sangat diperlukan untuk mengatasi krisis moral terutama pada fase remaja. Pada rentang usia ini, remaja dalam proses mencari identitas diri, memiliki keberanian yang berlebihan, lebih mementingkan teman sebaya, ingin diakui, mulai timbul ketertarikan pada lawan jenis, dan cenderung tidak realistis. Dalam prosesnya, remaja rentan terlibat berbagai masalah seperti perkelahian antar teman, meninggalkan shalat, mencuri, rendahnya rasa hormat terhadap orangtua dan guru, rendahnya nilai kejujuran yang berujung pada kebiasaan mencontek, maraknya bullying, kurang disiplin, pergaulan bebas, kurang peduli terhadap sesama, merokok, bolos sekolah, tawuran antar pelajar, dan sebagainya (Diananda, 2018: 120). Efeknya tidak hanya mempengaruhi kepribadian remaja, tetapi bisa menimbulkan keresahan dalam masyarakat. 
Intan Mayang Sahni Badry dan Rini Rahman: Upaya Guru Pendidikan Agama Islam dalam...

Banyak faktor yang dapat menyebabkan krisis moral di kalangan remaja baik faktor internal dan eksternal. Faktor internal (dari dalam) cenderung dipengaruhi oleh lemahnya kemampuan dalam mengontrol diri. Sedangkan, faktor eksternal (dari luar) seperti kurangnya perhatian dari orang tua, minimnya pemahaman terhadap keagamaan, dan pengaruh lingkungan (Sumara dkk, 2017: 347-349). Selain itu, penggunaan media sosial tanpa batasan dan pengawasan, lingkungan pertemanan yang kurang baik, maupun efek lingkungan yang cenderung membiarkan juga dapat berimbas terhadap krisis moral remaja. Jika krisis ini tidak ditangani secara tepat, remaja akan menganggap perilaku tersebut sebagai pembenaran dan layak dilakukan sehingga menjadi sebuah kebiasaan. Hal ini menandakan perlunya penguatan dan penanaman nilai-nilai karakter.

Secara khusus, karakter adalah nilai-nilai yang identik pada hal baik yaitu mengetahui nilai kebaikan, keinginan berbuat baik dan melakukannya. Sederhananya, karakter adalah kualitas perilaku yang dipengaruhi oleh pola kebiasaan dalam berpikir, hati, dan tindakan (Lickona, 2013: 82). Pendidikan berbasis karakter yang dikolaborasikan dengan pendidikan yang mengoptimalkan perkembangan seluruh dimensi peserta didik (kognitif, fisik, sosial-emosi, kreativitas, spiritual) akan berorientasi pada pembentukan kualitas peserta didik yang tidak hanya unggul dalam aspek kognitif, namun juga karakter. Sebab, anak yang karakternya unggul akan mampu menghadapi, mengatasi masalah serta tantangan dalam hidupnya (Rosita, 2018: 3). Nilai-nilai karakter termuat dalam Permendiknas No. 20 Tahun 2018 yang meliputi nilai religius, jujur, toleran, disiplin, bekerja keras, kreatif, mandiri, demokratis, rasa ingin tahu, semangat kebangsaan, cinta tanah air, menghargai prestasi, komunikatif, cinta damai, gemar membaca, peduli lingkungan, peduli sosial, dan bertanggung jawab.

Nilai karakter religius merupakan nilai utama yang menjadi pilar terbentuknya 17 nilai lainnya. Nilai ini dapat menjadi solusi dalam mengatasi krisis moral di kalangan remaja. Sebab, remaja yang di dalam dirinya telah tertanam nilai dan terbentuk karakter religius akan mampu mempertimbangkan baik dan buruk perbuatan yang akan ia lakukan atas dasar nilainilai agama, mengamalkan ajaran agama atas inisiatif sendiri, menghindarkan diri dari perbuatan yang tidak jujur seperti mencontek dan memberi contekan, berani mengakui kesalahan dan memperbaikinya. Selain dibutuhkan peran orang tua, guru juga bertanggung jawab untuk andil dalam menanamkan nilai karakter religius khususnya melalui pendidikan agama Islam.

Pendidikan agama Islam merupakan pilar utama sebagai sistem pendidikan moral dan akhlak dalam membentuk manusia yang bertaqwa kepada Allah Subhanahu wa Ta'ala (Djaelani, 2013: 104-105). Indikator karakter dalam hal ini yaitu iman dan takwa, pengendalian diri, sabar, disiplin, kerja keras dan ulet, bertanggung jawab dan jujur, membela kebenaran, kepatuhan, kesopanan dan kesantunan, taat pada peraturan, loyal, demokratis, sikap kebersamaan, musyawarah dan gotong royong, toleran, tertib, damai dan anti kekerasan, hemat serta konsisten (Prayitno \& Afriva, 2011: 16). Sebagai sumber ajaran pokok dalam Islam, Alquran dan sunnah telah membahas mengenai indikator tersebut. Seperti pengendalian diri yang dalam Alquran dikenal dengan istilah sabar (al-shabr) yaitu "Berilah kabar gembira kepada orang-orang yang sabar, yaitu orang-orang yang apabila ditimpakan kepada mereka musibah berkata bahwa sesungguhnya kami adalah milik Allah dan kepadaNya lah kami akan dikembalikan" (Q.S. al-Baqarah [2]: 156). Selain itu, Alquran juga berbicara tentang disiplin dan hemat dalam Q.S. al-'Asr [103]: 1-3, kerja keras dan ulet dalam Q.S. anNahl [16]: 97 dan HR. Muslim No. 3615, bertanggung jawab dan jujur dalam Q.S. al-Isra [17]: 36 dan HR. Bukhari No. 57, hormat dan santun dalam Q.S. al-Hujurat [49]: 11-12 dan dalam Q.S. ali-Imran [3]: 159, serta indikator lainnya (Kosasih dalam Khaidir, 2012: 23-27).

Karakter dalam Islam lebih dekat pada akhlak, dapat dilihat dalam Q.S. Luqman [31]: 2-19 yang menjelaskan cara Luqman menanamkan karakter pada anaknya dengan nasehat (maw'izah) seperti bersyukur kepada Allah Subhanahu wa Ta'ala, sikap terhadap orang tua, sikap dalam masyarakat, dan lainnya (Arif, 2015: 14-27). Meskipun makna antara karakter dan akhlak hampir sama, tetapi terdapat perbedaan antara keduanya yaitu akhlak hanya ada dalam ajaran Islam yang disandarkan pada Alquran dan al-Hadis, sedangkan karakter adalah 
istilah umum yang bisa digunakan semua agama. Ditinjau dari segi indikatornya, akhlak berhubungan dengan rohani dan indikator karakter erat kaitannya dengan jasmani.

Dalam penanaman nilai karakter terutama religius, peran pendidikan agama Islam sangat strategis sebagai sarana transformasi pengetahuan dalam aspek keagamaan, transformasi norma dan nilai moral untuk membentuk sikap yang berperan dalam mengendalikan perilaku sehingga tercapainya kepribadian yang utuh (Ainiyah, 2013: 26). Hal ini menuntut guru PAI harus bisa menjadi figur teladan, sebab karakter peserta didik juga merupakan manifestasi keteladanan yang dipengaruhi guru. Untuk menanamkan nilai karakter religius, guru pendidikan agama Islam dapat merancang skenario pembelajaran agar lebih kreatif dan variatif yang dapat meningkatkan keterlibatan peserta didik dalam pembelajaran dan memuat penanaman nilai karakter religius, membiasakan peserta didik dengan pengaplikasian, menyusun program ekstra keagamaan yang dilaksanakan secara rutin, memaksimalkan pelaksanaannya, dan mengevaluasi sebagai bahan pertimbangan dalam penanaman nilai karakter selanjutnya. Selain itu, dibutuhkan kerjasama antara orang tua dan guru sebagai penguatan agar nilai karakter religius yang ditanamkan guru sejalan dengan penerapannya di rumah. Sehingga, berbagai upaya ini diharapkan mampu menunjang optimalnya penanaman nilai karakter melalui pendidikan agama Islam.

Berdasarkan data observasi awal di SMP Negeri 40 Padang selama masa PLK dan wawancara pada tanggal 19 Februari 2021 dengan bapak Afdal Fauzen, S.Pd selaku guru pendidikan agama Islam di kelas IX bahwa dari segi karakter, peserta didiknya memiliki kelebihan terutama dalam nilai karakter religius. Tolok ukur karakter ini yaitu inisiatif peserta didik melaksanakan shalat dhuha di mushalla sekolah dan dilanjutkan membaca Alquran bergantian, serta menyetor hafalan Alquran melalui program tahfiz. Hal ini diupayakan guru PAI di dalam pembelajaran dan diluar pembelajaran. Khusus dalam pembelajaran, guru membuat skenario pembelajaran, membiasakan berdo'a sebelum dan sesudah pembelajaran, serta menekankan penanaman nilai religius melalui materi yang diajarkan. Sedangkan di luar pembelajaran, dilakukan melalui tahfiz, pembiasaan shalat dhuha, buku kontrol di rumah berupa buku agenda 18 - 21 sebagai penguatan pendidikan karakter dan kultum.

\section{Tinjauan Pustaka}

\section{A. Guru Pendidikan Agama Islam}

Dalam konteks pendidikan Islam, banyak kata yang mengacu pada pengertian guru seperti murabbi, mu'allim, dan mu'addib. Selain itu, guru kadang disebut melalui gelarnya seperti al-Ustadz dan asy-Syaikh. Hal ini dibahas lebih lanjut oleh Abuddin Nata, yaitu kata 'alim (bentuk jamaknya adalah 'ulama) atau mu'allim, yaitu orang yang mengetahui. Dalam istilah lain yaitu mudarris yang berarti pengajar (orang yang memberi pelajaran). Sementara itu, kata mu'addib merujuk kepada guru yang secara khusus mengajar di istana. Lain halnya dengan kata ustadz yang mengacu kepada guru agama yang khusus mengajar agama Islam. Sedangkan syaikh merujuk pada guru dalam bidang tasawuf (Minarti, 2016: 108). Selain itu, Roqib (2011: 22) memaknai guru merujuk pada orang yang bertugas dalam mencerdaskan kehidupan bangsa dalam semua aspek (spiritual, emosional, intelektual, fisikal, finansial maupun aspek lain).

Dakir dan Sardimi (2011: 31) berpendapat pendidikan agama Islam adalah rangkaian proses sistematis dan komprehenshif dalam upaya mentransfer berbagai nilai ke peserta didik, mengembangkan potensi yang ada, sehingga mampu melaksanakan tugasnya dalam hidup sesuai dengan nilai-nilai Ilahiyah berdasarkan ajaran agama (Alquran dan Hadits). Sedangkan pendidikan agama Islam dalam artian mata pelajaran dalam pandangan Ainiyah (2013: 30) merupakan pembelajaran yang wajib diajarkan pada setiap jenjang pendidikan yang berusaha menanamkan nilai-nilai spriritualitas agar peserta didik menjadi manusia yang berakhlak, beretika dan berbudaya sesuai tujuan pendidikan nasional. 
Intan Mayang Sahni Badry dan Rini Rahman: Upaya Guru Pendidikan Agama Islam dalam...

Dapat disimpulkan bahwa guru pendidikan agama Islam adalah pendidik yang membekali peserta didik untuk memahami berbagai ajaran agama serta turut andil dalam menanamkan nilai-nilai agama. Sehingga nantinya, peserta didik tidak hanya dituntut memahami, tetapi juga mengamalkan konteksnya dalam kehidupan serta outputnya adalah karakter maupun akhlak yang juga baik.

\section{B. Nilai Karakter Religius}

\section{Pengertian Nilai Karakter Religius}

Dari tinjauan bahasa, nilai berasal dari bahasa latin vale're yang artinya berguna, mampu akan berdaya, berlaku, sehingga nilai diartikan sebagai sesuatu yang dipandang baik, bermanfaat dan benar menurut keyakinan seseorang atau sekelompok orang (Adisusilo, 2012: 56). Sedangkan karakter dari segi bahasa (etimologis) diambil dari bahasa Inggris character, yang juga berasal dari bahasa Yunani character. Umumnya istilah character digunakan untuk mengartikan hal yang berbeda antara satu hal dan yang lainnya, dan akhirnya juga digunakan untuk menyebut kesamaan kualitas pada tiap orang yang membedakan dengan kualitas lainnya (Mu'in, 2016: 162). Prayitno dan Afriva (2011: 15) memaknai karakter sebagai sifat pribadi (ciri khas yang terwujud dari tingkah laku) yang konsisten dan menjadi landasan dalam bersikap yang dipengaruhi oleh standar nilai dan norma.

Implementasi pendidikan karakter telah terpatri dalam pribadi Rasulullah Shalallahu 'alaihi Wasallam. Dalam Q.S. al-Ahzab [33]: 70, menandakan bahwa pendidikan karakter dalam Islam telah ada sejak zaman Rasulullah yang mana Rasulullah sebagai role model.

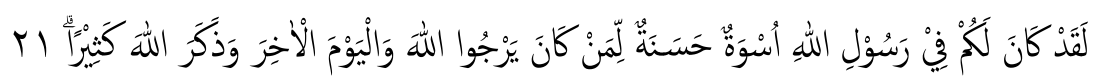

Sungguh, pada (diri) Rasulullah benar-benar ada suri teladan yang baik bagimu, (yaitu) bagi orang yang mengharap (rahmat) Allah dan (kedatangan) hari Kiamat serta yang banyak mengingat Allah. (Q.S. al-Ahzab [33]: 21)

Kurniawan (2017: 127) memaknai karakter religius sebagai sikap dan perilaku seseorang yang berkaitan spiritual yang dipengaruhi oleh kemauan dan usaha seseorang untuk mendekatkan dirinya pada Tuhan dengan patuh melaksanakan perintah agama. Internalisasi karakter ini sejak dini menurut Hambali (2018: 201), akan menguatkan moral peserta didik di masa yang akan datang, sehingga mereka tidak mudah terpengaruh pada hal-hal buruk.

Berdasarkan berbagai pendapat yang telah dijabarkan, karakter religius merupakan sikap yang mencerminkan kapasitas pemahaman terhadap ajaran agama yang dimanifestasikan dalam bentuk pengamalan dan membawa efek yang mencerminkan kepatuhan dan ketaatan terhadap Allah Subhanahu wa Ta'ala.

\section{Upaya Guru Pendidikan Agama Islam dalam Menanamkan Nilai Karakter Religius}

Dalam Sudrajat yang dikutip Zubaedi (2013: 163), pendidik atau guru dalam konteks pendidikan karakter dapat menjalankan lima peran. Pertama, konservator (pemelihara) nilai yang merupakan sumber norma kedewasaan. Kedua, inovator (pengembang) nilai ilmu pengetahuan. Ketiga, transmit (penerus) nilai kepada peserta didik. Keempat, transformator (penerjemah) nilai melalui pribadi dan perilakunya dalam interaksi dengan sasaran didik. Kelima, organisator (penyelenggara) terciptanya proses edukatif yang dapat dipertanggung jawabkan baik secara formal (kepada pihak yang mengangkat dan menugaskan) maupun moral (kepada sasaran didik dan Tuhan yang menciptakannya).

Dalam menanamkan dan membentuk karakter religius, Marzuki (2019: 110-111) merincikan program bercorak keagamaan yang bisa dijadikan sebagai pembiasaan, di antaranya: 1) mengucapkan salam saat membuka dan menutup pembelajaran dan do'a bersama, 2) sebelum memulai pembelajaran PAI, terlebih dahulu membaca Alquran, 3) shalat dhuha dengan jadwal bergantian setiap kelas, 4) Pembiasaan membaca Alquran 
sebelum shalat zuhur berjamaah, 5) Setiap pukul 06.30-07.30 membaca shalawat, istighfar, asmaul husna, atau kultum agama, 6) Melibatkan peserta didik dalam pelaksanaan PHBI di sekolah, 7) Memotivasi peserta didik ikut serta dalam aktivitas keagamaan di luar sekolah maupun di rumah, guru memantau peserta didik melalui komunikasi dengan orang tua serta buku khusus catatan harian keagamaan, dan 8) melaksanakan mabit.

Upaya yang dapat dilakukan guru pendidikan agama Islam dalam membangun karakter peserta didik dalam pandangan Sumarno (2016: 139-143), yaitu:

a. Mendidik dengan metode keteladanan, yang mana dalam membangun peserta didik yang berkarakter, guru harus memperlihatkan keteladanan dan nilai-nilai yang baik sebagaimana yang telah dilakukan Rasulullah Shalallahu 'alaihi Wasallam.

b. Melalui pembiasaan, diupayakan dengan membiasakan peserta didik untuk disiplin, mematuhi aturan sekolah, senyum kepada orang lain, dan pembiasaan melalui aktivitas lainnya.

c. Penerapan kebijakan pengawasan dan pendampingan bersama. Langkah ini perlu dilakukan dalam proses membentuk karakter dengan mengawasi semua kegiatan, tingkah laku, dan bicara peserta didik baik dalam pembelajaran maupun di luar kelas.

d. Memberi reward dan punishment. Hal ini penting dalam menanamkan nilai menghargai prestasi. Reward memberi efek positif yang memotivasi untuk meningkatkan belajarnya. Sedangkan punishment yang harus diberikan guru adalah hukuman yang mendidik dan memberi efek jera.

e. Pembinaan kedisiplinan. Guru dapat membantu peserta didik untuk mengembangkan pola perilaku, meningkatkan standarnya, dan menaati aturan yang menjadi alat penegakan disiplin.

f. Kerjasama dengan orang tua (co-parenting). Sekolah harus mempunyai rencana yang jelas dalam upaya membentuk karakter peserta didik yang dapat dilakukan bersama orangtua agar usaha ini dapat terwujud.

Upaya lain yang dapat diusahakan guru PAI sebagai pendidik yang berpotensi menguatkan penanaman nilai karakter, yaitu menjadi figur teladan yang sekaligus bisa menjadi tolak ukur karakter yang insan kamil, tanggap menengahi masalah yang terjadi antar peserta didik dan memberi masukan membangun, menanamkan pemahaman yang tepat mengenai karakter dan urgensi bagi peserta didik di masa depan. Sehingga secepat apapun perubahan yang disebabkan keluwesan inovasi teknologi, perubahan tersebut tetap dikawal dengan karakter agama.

\section{Metode}

Penelitian ini menggunakan jenis penelitian lapangan (field research) dengan menggunakan metode penelitian kualitatif. Gunawan (2017: 85) mendefenisikan penelitian kualitatif sebagai penelitian yang tujuannya untuk mendapatkan pemahaman mendalam mengenai masalah manusia dan sosial. Dalam penelitian ini, Peneliti berusaha memperoleh pemahaman terkait upaya guru PAI menanamkan nilai karakter religius di kelas IX SMP Negeri 40 Padang. Sumber data utama penelitian ini adalah guru pendidikan agama Islam kelas IX. Sedangkan sumber data pendukung yaitu wakil kesiswaan SMP Negeri 40 Padang, wakil kurikulum SMP Negeri 40 Padang, guru pendidikan agama Islam kelas VII dan VIII serta peserta didik kelas IX.

\section{Hasil dan Pembahasan}

Data yang disajikan disini ialah hasil penelitian lapangan dengan menggunakan teknik pengumpulan data observasi, wawancara dan dokumentasi. Berdasarkan hasil observasi, wawancara dengan 4 orang guru dan 4 orang peserta didik serta dokumentasi, ditemukan bahwa upaya guru pendidikan agama dalam menanamkan nilai karakter religius Islam memuat upaya di dalam dan di luar pembelajaran, yaitu: 
Intan Mayang Sahni Badry dan Rini Rahman: Upaya Guru Pendidikan Agama Islam dalam...

\section{a. Di Dalam Pembelajaran}

\section{1) Salam dan Berdo'a}

Praktek salam dan pembiasaan berdo'a ini dilakukan sebagai bentuk penanaman awal nilai karakter religius dalam diri peserta didik. Kurniawan (2017: 128) memaknai berdo'a sebagai bentuk rasa syukur kepada Allah Subhanahu wa Ta'ala. Syukur ini juga bisa diwujudkan melalui relasi atau persaudaraan dengan orang lain tanpa mempermasalahkan suku, ras, dan golongan. Berdo'a bertujuan agar peserta didik menyadari pentingnya melibatkan Allah ketika melakukan sesuatu. Selain itu, salam dan berdo'a dimaksudkan agar ilmu yang didapatkan dalam proses pembelajaran menjadi lebih berkah. Perintah berdo'a terdapat dalam Alquran:

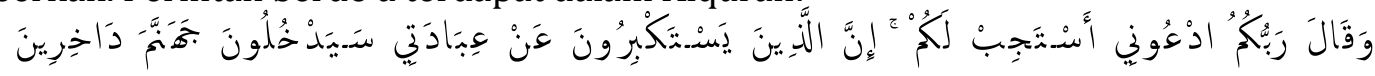

"Berdoalah kepada-Ku, niscaya akan Kuperkenankan bagimu. Sesungguhnya orangorang yang menyombongkan diri dari menyembah-Ku akan masuk neraka Jahannam dalam keadaan hina dina" (Q.S. al-Mu'min [40]: 60).

\section{2) Mengecek Shalat Siswa Melalui Absensi}

Shalat ialah menghadapkan dan menghadirkan hati untuk beribadah kepada Allah Subhanahu wa Ta'ala yang pelaksanaannya dalam bentuk perkataan dan perbuatan diawali dengan takbiratul ihram dan disudahi dengan salam serta dilakukan sesuai rukun dan syarat yang telah ditentukan dalam syari'at. Salah satu perintah untuk melaksanakan shalat terdapat dalam Alquran, yaitu:

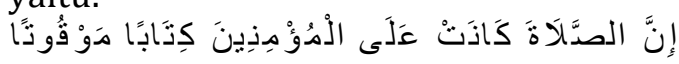

".... sungguh shalat itu adalah kewajiban yang ditentukan waktunya atas orangorang yang beriman." (Q.S. an-Nisa' [4]: 103)

Penanaman nilai karakter religius melalui shalat dengan pengecekan shalat yang direkap ketika mengambil kehadiran siswa. Hal ini terbilang efektif sebab secara tidak langsung akan menumbuhkan rasa malu jika peserta didik yang bersangkutan jujur meninggalkan shalat sehingga berujung pada kesadaran akan kewajiban sebagai hamba dan memotivasi peserta didik dalam melaksanakannya. Selain karakter religius, shalat juga melatih peserta didik untuk jujur, disiplin, percaya diri serta bertanggung jawab.

\section{3) Literasi Alquran}

Literasi Alquran di SMP Negeri 40 Padang dilaksanakan 3 kali seminggu. Program ini bukan hanya diperuntukkan bagi siswa kelas IX, tetapi juga untuk seluruh warga sekolah. Dalam pelaksanaannya, dikomandoi oleh guru agama melalui pengeras suara. Peserta didik dikondisikan di dalam kelas dengan membuka Alquran dan mengikuti bacaan Alquran. Ketersediaan fasilitas seperti speaker dan Alquran pada setiap kelas sangat memudahkan terlaksananya literasi Alquran di SMP Negeri 40 Padang. Selain kegiatan membaca, peserta didik juga diarahkan untuk memahami kandungan ayat Alquran yang dibaca. Pembiasaan literasi ini turut diberi penguatan oleh guru agama dengan mengarahkan peserta didik membaca Alquran secara bergantian setiap pembelajaran pendidikan agama Islam. Setelah itu, guru menjelaskan makna ayat tersebut dan menghubungkannya dengan konteks nyata maupun dengan materi yang akan dipelajari.

Literasi dipahami sebagai mendengar, membaca, menulis, dan berbicara. Sedangkan literasi Alquran didefenisikan sebagai kemampuan individu dalam membaca, memahami pesan dan makna yang disampaikan dalam Alquran, maupun tujuan dan ajarannya. Literasi Alquran ini tidak bisa dilepaskan dari perintah membaca Alquran yaitu:

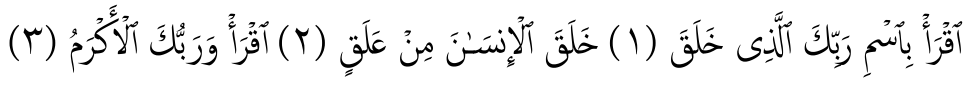


"Bacalah dengan (menyebut) nama Tuhanmu Yang menciptakan. Dia telah menciptakan manusia dari segumpal darah. Bacalah, dan Tuhanmulah Yang Maha Pemurah." (Q.S. al-'Alaq [96]: 1-3)

Pada ayat tersebut, sering disebutkan kata 'iqra' yang berarti menunjukkan pentingnya membaca sebagai perintah Allah yang pertama terhadap manusia. Meskipun tidak dijelaskan secara khusus mengenai konteks atau objek bacaan, artinya mengandung kebolehan untuk membaca apapun yang dapat mendatangkan manfaat termasuk Alquran. Berikut manfaat membaca dalam Istianah (2015: 206) yaitu melatih dan mengasah otak, mengurangi stress dan memberi efek rileks, meningkatkan konsentrasi, menambah wawasan dan ilmu, mengembangkan pola tidur yang sehat, menjauhkan dari resiko penyakit alzheimer (pelupa), memperkaya kosakata, mengasah kemampuan menulis dan public speaking.

\section{4) Pembiasaan Shalat Dhuha}

Pembiasaan adalah sesuatu yang dilakukan secara terus-menerus agar bisa menjadi rutinitas dan menanamkan sikap konsisten. Mendidik dengan pembiasaan ini menjadi urgensi yang bertujuan agar karakter religius dapat tertanam dalam diri peserta didik. Sehingga, secara tidak langsung juga membentuk 17 nilai karakter lainnya. Sejalan dengan pendapat Shoimah (2018: 173) bahwa melalui pembiasaan, peserta didik belajar mengenai yang benar dan salah, merasakan dan dapat membedakan nilai yang baik dan tidak serta dapat mempertimbangkan melakukannya atau tidak. Sehingga, tingkah laku yang dibentuk melalui pembiasaan akan menjadi karakter. Salah satu bentuk pembiasaan di SMP Negeri 40 Padang adalah pelaksanaan shalat dhuha secara rutin terutama ketika pembelajaran pendidikan agama Islam. Selain itu, jadwal pembelajaran juga mendukung shalat ini untuk menjadi pembiasaan dengan tersedianya waktu khusus dhuha pada jam 09.35-10.20 WIB.

Pembiasaan shalat dhuha di SMP Negeri 40 Padang ditunjang oleh keteladanan yang dipengaruhi guru agama. Sejalan dengan pendapat Sumarno (2016: 139-140), yaitu mendidik dengan keteladanan diperlukan dalam membangun peserta didik yang berkarakter, guru harus memperlihatkan keteladanan dan nilai-nilai yang baik sebagaimana yang telah dilakukan Rasulullah Shalallahu 'alaihi Wasallam. Keteladanan dari Rasulullah digambarkan dalam Alquran, yaitu:

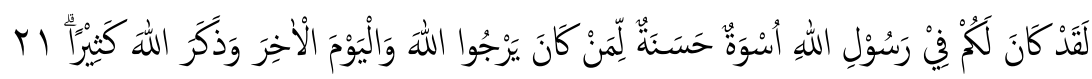

Sungguh, pada (diri) Rasulullah benar-benar ada suri teladan yang baik bagimu, (yaitu) bagi orang yang mengharap (rahmat) Allah dan (kedatangan) hari Kiamat serta yang banyak mengingat Allah. (Q.S. al-Ahzab [33]: 21)

Ayat tersebut menunjukkan posisi Rasulullah sebagai figur teladan yang sepatutnya dijadikan sebagai role model bagi umat Islam dari segala aspek seperti keimanan, perkataan, perbuatan (adab, akhlak, karakter), bahkan gaya hidup beliau. Sifat Rasulullah tercakup dalam 4 sifat yaitu siddiq (jujur), amanah (dapat dipercaya), fathanah (cerdas), serta tabligh (menyampaikan).

\section{5) Infaq}

Infaq adalah menyisihkan sebagian harta guna kepentingan sosial kemanusiaan sesuai syariat Islam. Berarti dalam prosesnya, terdapat pelepasan hak dan memutus kepemilikan sebagaian harta kepada pihak yang lebih membutuhkan. Pengadaan infaq ini melatih kepedulian sosial peserta didik, membangun rasa ikhlas dan menanamkan rasa syukur di dalam diri. Infaq di SMP Negeri 40 Padang dikumpulkan setiap jum'at dengan arahan dari guru agama. Hasil dari infaq ini difungsikan untuk pelaksanaan semua kegiatan yang berkaitan agama. Anjuran berinfaq yang terdapat di dalam Alquran, yaitu:

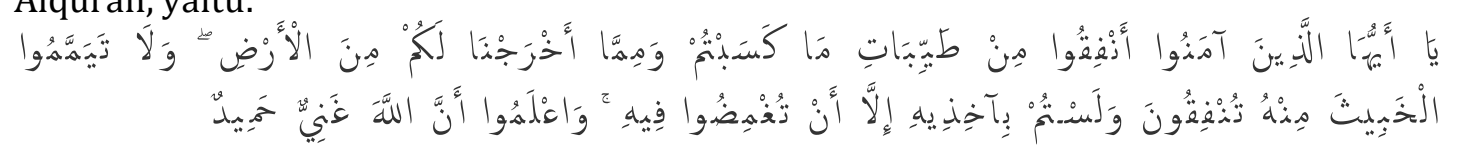


Intan Mayang Sahni Badry dan Rini Rahman: Upaya Guru Pendidikan Agama Islam dalam...

"Hai orang-orang yang beriman, nafkahkanlah (di jalan allah) sebagian dari hasil usahamu yang baik-baik dan sebagian dari apa yang Kami keluarkan dari bumi untuk kamu. Dan janganlah kamu memilih yang buruk-buruk lalu kamu menafkahkan daripadanya, padahal kamu sendiri tidak mau mengambilnya melainkan dengan memincingkan mata terhadapnya. Dan ketahuilah, bahwa Allah Maha Kaya lagi Maha Terpuji." (Q.S. al-Baqarah [2]: 267)

\section{b. Di luar Pembelajaran}

\section{1) Program Tahfizh}

Menurut Fachrudin (2017: 330), tahfizh Alquran adalah proses menghafal Alquran bertujuan menjaga, memelihara, dan mengingat Qur'an dengan tetap memperhatikan adab terhadap Alquran. Ini menjadi langkah awal untuk memahami kandungan Alquran setelah proses membacanya. Allah berfirman:

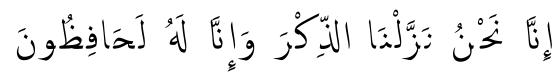

"Sesungguhnya Kami yang menurunkan al-Quran dan sesungguhnya Kami benarbenar memeliharanya." (Q.S al-Hijr [15]: 9)

Dari hasil temuan penelitian, program tahfizh di SMP Negeri 40 Padang berupa penghafalan Alquran dengan target hafalan surah an-Naba', an-Nazi'at, Abasa, at-Takwir, hingga surah al-Infitar. Program ini wajib diikuti oleh seluruh peserta didik dengan guru agama selaku mentor. Teknis penyetorannya baik secara langsung atau bisa dengan mengirim video hafalan kepada guru mentor sesuai jadwal yang telah ditentukan maupun tidak sesuai jadwal. Guru mentor berkewajiban mengarahkan, membimbing, meluruskan bacaan peserta didik, serta merekap hafalan.

\section{2) Wirid Pagi Jum'at}

Wirid pagi Jum'at dilaksanakan secara rutin dalam dua bentuk yaitu muhadharah dan kultum. Sebelum pandemi, wirid ini dilaksanakan dalam bentuk muhadharah dengan melibatkan dan memberi tanggung jawab peserta didik untuk mengisi kegiatan seperti pembawa acara, membaca Alquran dan terjemahan, berdakwah serta dilanjutkan dengan ceramah agama sebagai penguatan yang disampaikan guru agama atau dengan mengundang ustadz/ustadzah.

Muhadharah adalah kegiatan yang bertujuan mengasah kemampuan peserta didik dalam berdakwah. Dari segi objek dakwah, muhadharah memiliki tujuan menurut Setiawan (2015: 307-309) jika dihubungkan pada peserta didik, yaitu a) terbentuknya pribadi yang beriman, berperilaku sesuai hukum yang disyariatkan Allah, b) tertanamnya akidah yang mantap dalam diri peserta didik, sehingga keyakinan terhadap agama tidak diliputi keraguan, c) ketaatan terhadap hukum-hukum yang disyariatkan, d) terbentuknya pribadi yang berbudi, dihiasi dengan sifat terpuji, dan bersih dari sifat tercela. Dari semua tujuan ini muaranya pada akhlak dan karakter. Berikut perintah untuk berdakwah dalam firman Allah:

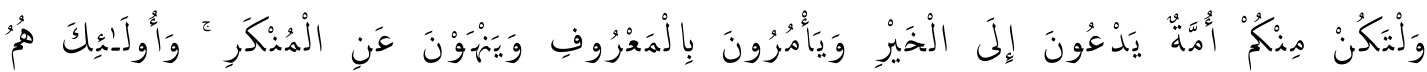

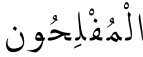

"Dan hendaklah ada di antara kamu segolongan umat yang menyeru kepada kebajikan, menyuruh kepada yang ma'ruf dan mencegah dari yang munkar; merekalah orang-orang yang beruntung." (Q.S. ali-Imran [3]: 104)

Karena terkendala situasi pandemi, pelaksanaan muhadharah dialihkan dalam bentuk kultum dengan teknis pelaksanaan oleh guru agama dengan merekam video berisi kultum atau dengan mengambil video dari ustadz lain. Kemudian, guru agama mengirim link video kultum ke grup whatsapps parenting. Video tersebut bisa diakses oleh peserta didik 
melalui youtube, peserta didik diharuskan menyimak dan menyimpulkan isi kultum tersebut di buku agenda 18-21.

\section{3) Nasehat}

Dalam penanaman nilai karakter religius, diperlukan penguatan seperti nasehat. Agar nilai yang berusaha ditanamkan oleh guru lebih mudah diterima peserta didik. Nasehat ini bertujuan untuk mengingatkan dan mengarahkan peserta didik dalam bersikap dan melakukan sesuatu. Nasehat yang diberikan guru pendidikan agama didukung dengan membangun komunikasi yang baik sehingga memudahkan guru menginput nasehat kepada peserta didik seperti mengingatkan agar tidak berkata kotor dan mengarahkan untuk menerapkan adab ketika makan. Nasehat ini bersifat spontan, dilakukan oleh guru ketika melihat peserta didik melakukan hal yang kurang baik. Sedangkan upaya penanaman nilai karakter religius bentuk ajakan dilakukan guru pendidikan agama Islam kelas IX dengan mengajak siswa untuk melaksanakan shalat berjamaah. Berbagai upaya guru ini sesuai dengan perintah Allah untuk mengajak pada kebaikan dan mendirikan shalat seperti nasehat yang diberikan Luqman kepada anaknya:

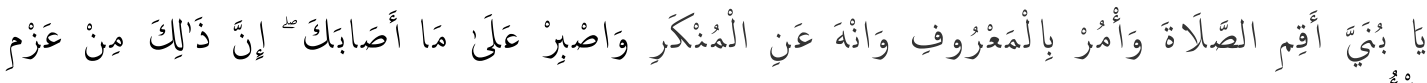

$$
\begin{aligned}
& \text { الأَُْورِ }
\end{aligned}
$$

"Hai anakku, dirikanlah shalat dan suruhlah (manusia) mengerjakan yang baik dan cegahlah (mereka) dari perbuatan yang mungkar dan bersabarlah terhadap apa yang menimpa kamu. Sesungguhnya yang demikian itu termasuk hal-hal yang diwajibkan (oleh Allah)." (Q.S. Luqman [31]: 17)

Menurut Sumarno (2016: 141-142), nasehat sangat berhubungan dengan penerapan kebijakan pengawasan dan pendampingan bersama. Langkah ini diperlukan dalam proses membentuk karakter dengan mengawasi semua kegiatan, tingkah laku, dan bicara peserta didik baik dalam pembelajaran maupun di luar kelas.

\section{4) Shalat Berjamaah}

Upaya penanaman nilai karakter religius juga dilakukan guru pendidikan agama Islam kelas IX dengan mengajak peserta untuk melaksanakan shalat berjamaah. Ajakan untuk shalat ini biasanya dilakukan guru ketika melihat peserta didik yang masih berkumpul saat pulang sekolah sedangkan waktu shalat sudah masuk. Selain itu, ketika pembelajaran agama di jam terakhir, guru juga mengarahkan peserta didik untuk shalat berjamaah sebelum pulang. Upaya guru ini sesuai dengan perintah Allah untuk mengajak pada kebaikan dan mendirikan shalat seperti nasehat yang diberikan Luqman kepada anaknya:

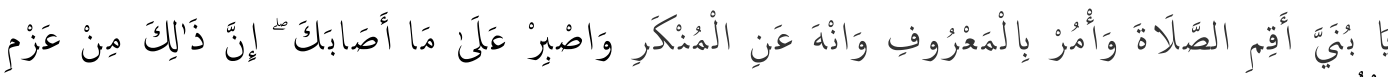

$$
\begin{aligned}
& \text { الأُْْورِ }
\end{aligned}
$$

"Hai anakku, dirikanlah shalat dan suruhlah (manusia) mengerjakan yang baik dan cegahlah (mereka) dari perbuatan yang mungkar dan bersabarlah terhadap apa yang menimpa kamu. Sesungguhnya yang demikian itu termasuk hal-hal yang diwajibkan (oleh Allah)." (Q.S. Luqman [31]: 17

\section{5) Komunikasi dengan Orang Tua}

Dalam mengoptimalkan penanaman nilai karakter religius, dibutuhkan peran orangtua pada prosesnya. Agar berbagai program dan upaya yang telah dilakukan guru di sekolah, searah dengan pola penerapannya di rumah. Hal ini sejalan dengan fungsi keluarga menurut Badan Kependudukan dan Keluarga Berencana Nasional (BKKBN) terutama fungsi dalam agama yang bermakna bahwa keluarga adalah wadah pembinaan kehidupan beragama yaitu iman dan taqwa kepada Allah dan segala sesuatu yang dilakukan 
Intan Mayang Sahni Badry dan Rini Rahman: Upaya Guru Pendidikan Agama Islam dalam...

seharusnya berpijak atas dasar agama (Kurniawan, 2017: 44). Urgensi keterlibatan orangtua dalam penanaman nilai karakter dalam hadis:

Dari Abi Hurairah, Rasulullah Shalallahu 'alaihi Wasallam bersabda "Setiap anak dilahirkan dalam kondisi fitrah kecuali orangtuanya yang menjadikannya Yahudi, Nasrani, atau Majusi." (HR. Bukhari Muslim)

Sumarno (2016: 143) berpendapat untuk menjalin kerjasama dengan orang tua (coparenting), pihak sekolah maupun guru yang bersangkutan harus mempunyai rencana yang jelas dalam upaya membentuk karakter peserta didik yang dapat dilakukan bersama orangtua agar usaha ini dapat terwujud.

Komunikasi dengan orangtua dibangun oleh SMP Negeri 40 Padang dengan fasilitas berupa buku penguatan pendidikan karakter (PPK) bertajuk buku agenda 18-21 yang memuat pelaksanaan shalat wajib, lembaran khusus merangkum isi muhadharah, ibadah sunnah seperti shalat sunnah, membaca Alquran, puasa senin-kamis, membantu orang tua. Buku ini diisi oleh peserta didik dan diketahui orangtua serta diserahkan kepada guru agama untuk dinilai. Sejalan dengan pendapat Murniyetti dkk (2016: 160-161) mengontrol ibadah siswa di rumah melalui buku kontrol ibadah harian yang di dalamnya mencakup shalat dan membaca Alquran. Sedangkan bimbingan kerohanian secara rutin dilakukan melalui ceramah agama. Dua upaya ini dilakukan untuk mematangkan pemahaman siswa terhadap ajaran Islam.

\section{6) Kerjasama dengan Masjid}

Tempat ibadah dapat menjadi pusat penanaman nilai karakter religius dengan menyelenggarakan berbagai kegiatan kegamaan baik bersifat rutin maupun temporer. Kegiatan rutin seperti shalat berjamaah, kajian kitab, kultum, pengajian bulanan, maupun TPA. Sedangkan kegiatan temporer seperti PHBI dan kegiatan di bulan Ramadhan (Kurniawan, 2017: 205). Dari hasil penelitian, kerjasama ini terjalin dengan masjid sebagai pihak pelaksana guna menginput nilai religius terhadap peserta didik dengan pemberian ceramah agama. Dalam hal ini, guru agama bertanggung jawab menyusun pergantian jadwal dan mengkoordinasikannya dengan wali kelas. Kegiatan ini dilakukan setiap hari Sabtu sesuai tingkatan kelas dan diisi dengan ceramah agama. Hal ini tentu sangat membantu dalam penanaman nilai karakter religius. Sebab, selain upaya yang telah dilakukan guru agama dan pihak sekolah, komunikasi dengan orang tua, juga turut diberi penguatan oleh masyarakat sekitar. Kerja sama digambarkan dalam firrman Allah:

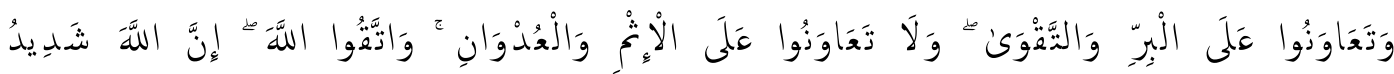

$$
\begin{aligned}
& \text { الْعِعَابِ }
\end{aligned}
$$

"Dan tolong-menolonglah kamu dalam (mengerjakan) kebajikan dan takwa, dan jangan tolong-menolong dalam berbuat dosa dan pelanggaran. Dan bertakwalah kamu kepada Allah, sesungguhnya Allah amat berat siksa-Nya. (Q.S. al-Maidah [5]: 2)

\section{Simpulan}

Berdasarkan hasil penelitian yang telah penulis paparkan, dapat disimpulkan bahwa upaya guru pendidikan agama Islam dalam menanamkan nilai karakter religius di kelas IX SMP Negeri 40 Padang mencakup upaya di dalam pembelajaran dan di luar pembelajaran. Upaya di dalam pembelajaran ditanamkan guru dengan salam dan berdo'a, mengecek shalat siswa melalui absensi, literasi Alquran, pembiasaan shalat dhuha, dan infaq. Sedangkan penanaman nilai karakter religius di luar pembelajaran melalui program tahfizh, wirid pagi Jum'at, nasehat, shalat berjamaah, komunikasi dengan orangtua, dan kerjasama dengan masjid.

\section{Referensi}


Adisusilo, Sutarjo. (2012). Pembelajaran Nilai - Karakter: Konstruktivisme dan VCT sebagai Inovasi Pendekatan Pembelajaran Afektif. Jakarta: PT Raja Grafindo Persada.

Ainiyah, Nur. (2013). Pembentukan Karakter Melalui Pendidikan Agama Islam. Jurnal alUlum, 13(1).

Arif, Muh. (2015). Nilai-Nilai Pendidikan Karakter dalam Alquran (Studi Q.S. Luqman: 12-19). Jurnal Irfani, 11(1).

Dakir, \& Sardimi. (2011). Pendidikan Islam \& ESQ: Komparasi-Integratif Upaya Menuju Stadium Insan Kamil. Semarang: Rasail Media Group.

Diananda, Amita. (2018). Psikologi Remaja dan Permasalahannya. Jurnal Istighna, 1(1).

Djaelani, Moh Solikodin. (2013). Peran Pendidikan Agama Islam dalam Keluarga dan Masyarakat. Jurnal Ilmiah Widya, 1(2).

Fachrudin, Yudhi. (2017). Pembinaan Tahfzh Alquran di Pesantren Tahfizh Daarul Qur'an Tangerang. Jurnal Kordinat, 16(2).

Gunawan, Imam. (2017). Metode Penelitian Kualitatif: Teori dan Praktik Ed. 1, Cet. 5. Jakarta: Bumi Aksara.

Hambali, Muh, \& Eva Yulianti. (2018). Ekstrakurikuler Keagamaan Terhadap Pembentukan Karakter Religius Peserta Didik di Kota Majapahit. Jurnal Pedagogik, 5(2).

Istianah. (2015). Melalui Perpustakaan Kita Budayakan Falsafah Iqra'. Kudus: STAIN Kudus.

Kosasih, Ahmad. (2012). Pembinaan Karakter Mahasiswa melalui PAI. Dalam Khaidir, Afriva (Ed.). Pendidikan Karakter: Sebuah Refleksi Pendekatan dalam Illmu Humaniora. Padang: Sukabina Press.

Kurniawan, Syamsul. (2017). Pendidikan Karakter: Konsepsi \& Implementasinya secara Terpadu di Lingkungan Keluarga, Sekolah, Perguruan Tinggi, dan Masyarakat. Yogyakarta: ar-Ruzz Media.

Lickona, Thomas. (2013). Mendidik untuk Membentuk Karakter: Bagaimana Sekolah dapat Memberikan Pendidikan tentang Sikap Hormat dan Bertanggung jawab. Terjemahan Juma Abdu Wamaungo. Jakarta: Bumi Aksara.

Marzuki. (2019). Pendidikan Karakter Islam. Jakarta: Amzah.

Minarti, Sri. (2016). Ilmu Pendidikan Islam: Fakta Teoritis-Filosofis dan Aplikatif-Normatif. Jakarta: Amzah.

Mu'in, Fatchul. (2016). Pendidikan Karakter: Konstruksi Teoritik \& Praktik. Jogjakarta: Ar-Ruzz Media.

Murniyetti, Engkizar, dan Fuady Anwar. (2016). Pola Pelaksanaan Pendidikan Karakter terhadap Siswa Sekolah Dasar. Jurnal Pendidikan Karakter, VI (2).

Prayitno, \& Afriva Khaidir. (2011). Model Pendidikan Karakter-Cerdas. Padang: UNP Press.

Roqib, Moh. (2011). Kepribadian Guru sebagai Upaya Mengembangkan Kepribadian Guru yang Sehat di Masa Depan. Purwokerto: STAIN Purwokerto Press.

Rosita, Lilis. (2018). Peran Pendidikan Berbasis Karakter dalam Pencapaian Tujuan Pembelajaran di Sekolah. Jurnal Ilmu Politik dan Komunikasi, VIII (1).

Setiawan, Eko. (2015). Strategi Muhadharah sebagai Metode Pelatihan Dakwah bagi Kader Da'i di Pesantren Daarul Fikri Malang. Jurnal Fenomena, 14(2).

Shoimah, Lailatus, Sulthoni, \& Yeri Soepriyanto. (2018). Pendidikan Karakter melalui Pembiasaan di Sekolah Dasar. Jurnal JKTP, 1(8).

Sumara, Dadan, Sahadi Humaedi, \& Meilanny Budiarti Santoso. (2017). Kenakalan Remaja dan Penanganannya. Jurnal Penelitian \& PPM, 4(2).

Sumarno. (2016). Peranan Guru Pendidikan Agama Islam dalam Membangun Karakter Peserta Didik. Jurnal Al Lubab, 1(1).

Zubaedi. (2013). Desain Pendidikan Karakter: Konsepsi dan Aplikasinya dalam Lembaga Pendidikan. Jakarta: Kencana Prenada Media Group. 